\title{
Analysis of the Implementation of Smart Indonesia Program through Indonesia Smart Card in Palembang City 2016
}

\author{
Dwi Mirani, Sylvie Agustina, and Shinta Desiyana F \\ Faculty of Social and Political Sciences, Sriwijaya University \\ miranidwi@gmail.com
}

\begin{abstract}
The dropout rate in Indonesia is quite high, therefore it is the responsibility of the government to overcome this situation. During the reign of President Joko Widodo, a policy called Smart Indonesia Program was aimed at increasing primary and secondary education enrollment rates, to increase education sustainability and reducing educational disparities in Indonesia. The early stages of the Smart Indonesia Program was established through the distribution of Indonesia Smart Card. This study aims to see the success of Indonesia Smart program through Indonesia Smart Card in Palembang City. Data collection was obtained by interview, observation, and documentation which was conducted in two executive agencies, the district education office of Palembang city and the office of Ministry of Religions in Palembang. Accuracy data test by the data triangulation process was conducted by involving the school administrators and students who received Indonesia Smart Card. This research uses Implementation model from Van Meter and Horn. The results of this study show that Smart Indonesia Program has been successfully implemented in the objectives, yet it still not optimal. From the research result, it is found that the coordination and communication in this program need improvement, on the other hand, there are some other findings in the form of expired and inaccurate the data, inaccurate targets of Indonesia Smart Card, and the lack of communication to private schools, therefore it is recommended to perform data updating and to ensure direct involvement of the school in determining which student should receive Indonesia Smart Card.
\end{abstract}

Keyword: Implementation, Smart Indonesia Program, Indonesia Smart Card.

\section{Introduction}

Human resources are the basic capital of National Development. Human resources (HR) is a critical determinant of the success of development in a country. Human as resources must have the quality and competence in order to compete in the domain of life. In addition, the government as the holder of the people's mandate should encourage the improvement of the quality of human resources. In the preamble of the 1945 Constitution, the fourth paragraph states that Indonesia has a state goal which one of them reads "enrich the nation's life" means that the State guarantees education to create an intelligent society. Therefore, through the field of education the government seeks to realize the purpose of the State. Various efforts made by the government to improve the quality of education in Indonesia such as curriculum improvement, infrastructure development, improving the quality of teachers, provision of supporting facilities, the provision of scholarship assistance and so forth.

Improving the quality of education and human resources development which qualified require a lot of funds. In terms of the allocation of education funds, the Government has allocated special allocation funds for education in the implementation of education in Indonesia. One of them with 'Bantuan Operasional Sekolah' funds or BOS. Through BOS 
funds children can have school free without any additional costs. However, even though schools have made the cost free, parents still need to be able to provide personal funds for school support purposes for their children. In fact, people at lower levels or low-income groups tend not to be able to send their children to school. Lack of school fees can make children lose their chance to go to education or go to higher levels (dropping out of school).

The dropout rate in Indonesia is still quite high. This can be seen from the data of the Ministry of Education and Culture (Kemendikbud). Based on data, in 2015-2016 there are about 946,013 students who graduated from elementary school who were unable to continue to middle level (SMP). This is worsened with data 51,541 people the number of students who continue their education to junior high school did not pass. Which means, there are 997,445 Indonesian children who are only certified elementary school in 2015 until 2016. (http://www.jawapos.com)

To overcome these problems, then during the current governement of president Joko Widodo, created the Smart Indonesia Program. Smart Indonesia Program (PIP) is one of the national programs listed in the RPJMN 2015-2019 which aims to increase primary and secondary education enrollment rates, increase education sustainability figures that can be seen from decreasing dropout rates and to decrease inequalities in educational participation between community groups, between the rich and the poor, in the city and in the village, and between regions in Indonesia. This program is an improvement program of poor student assistance program after ending at the end of 2014. Through this program the government seeks to prevent learners from the possibility of dropping out of school, and is expected to attract dropout students to continue their education. PIP is also expected to ease the educational personal costs of learners, either directly or indirectly. PIP funds can be used to help students' personal expenses, such as purchasing school supplies/courses, pocket money and transportation costs, additional practical fees and competency test fees.

Since the launch of the Smart Indonesia Program through KIP in 2014, the program has undergone many developments. In the beginning, many obstacles were faced, especially on the problem of data collection and distribution of Indonesia Smart Card, the lack of participation of local governments, both districts and villages in the implementation of Indonesia Smart Card distribution, so this card becomes a target, because the data received by the central government is not in accordance with field data, Unclear data used in KIP distribution occurs due to lack of data updating.

Related to Smart Indonesia Program (PIP) and Dapodik data (Basic Education Data) can be used as a reference in data collection process in BPS. From data of KIP recipients sourced from BPS and have been processed by TNP2K as many as 17,9 million school-aged children from poor families are entitled to receive KIP, which has distributed by Kemdikbud. From those amounts, 13.7 (76,6 \%) million children in school and 4.2 (23.4\%) million nonschool children are enrolled. After the distribution of KIP Card many data accuracy problems are found in the field. Then matching with Dapodik Data. A total of 5 million children corresponded to Dapodik data, while 12.9 did not correspond to Dapodik data (Basic Education Data). Even so it can not be concluded that 12,9 also the child is out of school. It is still necessary to apply KIP data, between the data of the CPP that has been processed by TNP2K, which identifies school-aged children (6-21 years old) from poor families with Dapodik containing 44.5 million students enrolled in school (http://www.edupost.id). 
Yet, there are also problem of the public knowledge conceiving about the benefits of Indonesia Smart Card, causing the people who get the Indonesian Smart Card from Government feel confused and do not know what to do with the card due to lack of socialization from the government about how the use of the KIP. Thus, there are so many complaints that come from the community, which makes the government should immediately follow up so that the problem does not occur protracted and cause new problems. (http://www.dakwatuna.com) according to thus problem we know that some of the problem come from the Top level implementor, that mean, the research must looking theory to solve this problem which can see problem from that side.

Smart Indonesia Program implemented in several provinces in Indonesia, in South Sumatra this program is in line with work program of Governor, South Sumatera, Alex Noerdin is free school program (Sekolah Gratis), therefore this program can support the implementation of free school program in South Sumatera. although there are already free school programs but the dropout rate in South Sumatra is quite high.

In the city of Palembang, in 2016, the Indonesian Smart Card recipients reached 103,693 people. Implementation of KIP at the city level implemented by Disdikpora Palembang now (as of 1 January 2017) changed its name to the Education Department of Palembang City. There are several problems that arise related to the implementation of KIP in the city of Palembang such as the neglect of students and parents/guardians in reporting the ownership of Indonesia Smart Card (KIP) to the school side to get assistance tuition fees for poor families, often the main factor is not distribute the funds from the central government. In the data collection KIP ownership there is also a deadline, which is usually a maximum of 3 months after the implementation of the new school year learning. Mainset or parent/guardian thought pattern must be changed, because not necessarily after getting or registered in KIP program they directly accept the aid. (http://www.korankito.com)

Seeing so many problems that exist in the implementation of the Smart Indonesia Program through KIP government is required to provide the best solution in the sustainability of the program, its assumption if the implementation of this program runs well then the program performance can be said either. For that reason, in this research, analysis of the implementation of Smart Indonesian Program through Indonesia Smart Card in Palembang City 2016.

\section{Literature Review}

\section{Policy Implementation}

Any policy that has been established by the policymaker should be able and successfully implemented. Implementation of a program involves policy makers efforts to influence the conduct of the executing bureaucrats to be willing to provide service and manage the behavior of the target group.

Implementation by Van Meter and Van Horn in The Policy Implementation Process: a Conceptual Framework, explains that:

"Implementation is actions undertaken by individuals or officials or government or private groups directed at achieving the objectives outlined in policy decisions" (Meter and Vanhorn, 1975: 447). 
Daniel Mazmanian and Paul Sabatier in his book Implementation and Public Policy described implementation as:

"The implementation of the basic policy decisions, usually in the form of legislation, but can also form orders or judgments to messenger or important executive or judicial decision. Normally, the decision identifies the problem to be addressed, explicitly states the objectives or targets to be achieved, and the various ways to structure or organize the implementation process "(Mazmanian and Paul Sabatier 1983: 61).

Based on this understanding, policy implementation is a very important step in the policy process. Without implementation, a policy is merely a meaningless document in social life. Many good policies, which can be made by the government, which are formulated by using experts from within the country, or using experts from abroad, nevertheless apparently have no effect whatsoever in the life of the country because incapable or not implemented.

\section{Factors Affecting Policy Implementation}

The success of policy implementation is determined by many variables or factors, and each variable relates to one another. Van Meter and Van Horn suggest there are six variables that can affect the success/performance of the implementation called A Model of The Policy Implementation, namely:

\section{Figure 1}

\section{Van Meter and Van Horn Policy Implementation Model}

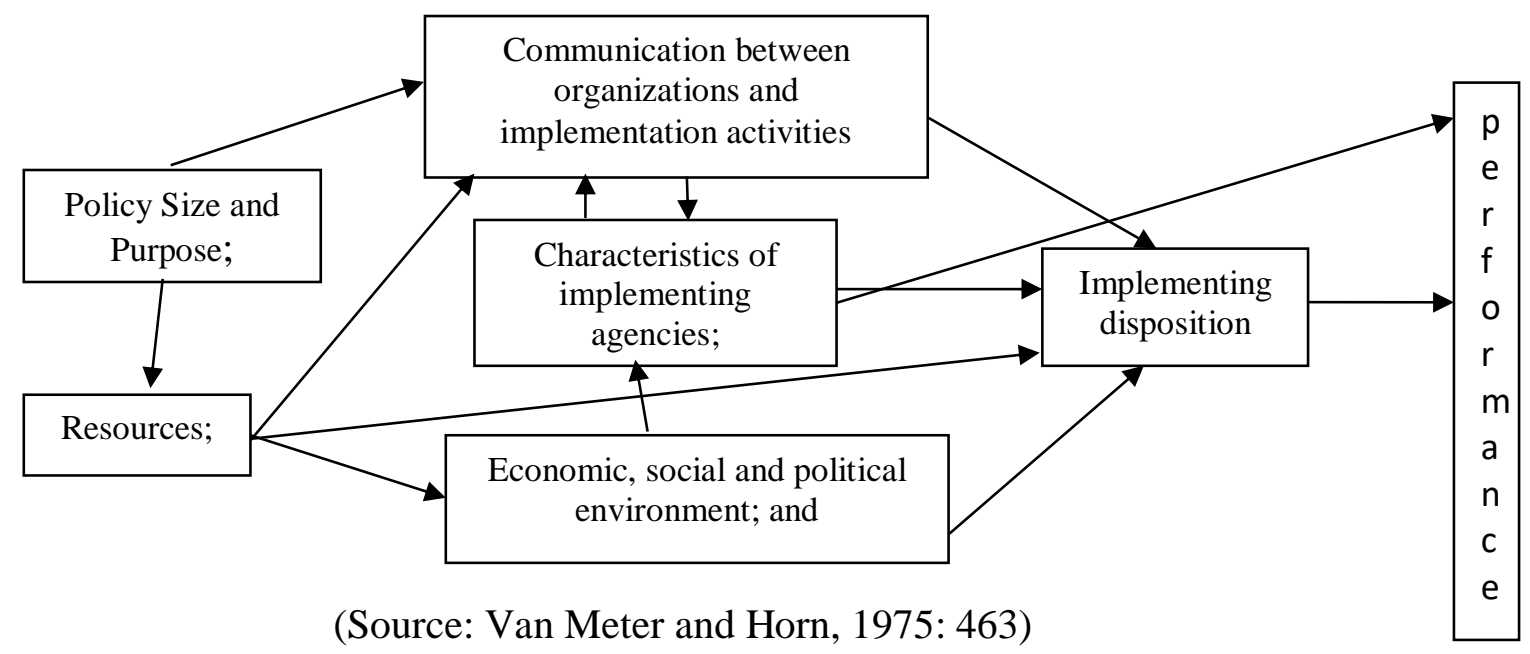

This process is an abstraction or performance of a policy that is basically done to achieve the performance of high public policy implementation, which takes place in the relationship of various variables. This model likens linear implementation of the policy in a linear manner from available political decisions, implementers, and public policy performance.

First, according to Van Meter and Van Horn, the size and objectives of the policy are needed to direct in implementing the policy, it is done to fit the planned program.

Second, according to Van Meter and Van Horn, policy resources are the success of the policy implementation process that is influenced by the utilization of human resources, cost, and time (Meter and Van Horn, 1975: 465). Human resources are very important because as a source of drivers and policy implementers, capital is needed to smooth the financing of the 
policy so as not to impede the policy process. Time needed to support the success of the policy. Time resources are the determinants of government in planning and implementing policies.

Third, the success of the policy can be seen from the nature or characteristics of the implementing agency/agency. This is very important because the performance of public policy implementation will be greatly influenced by the appropriate characteristics and fit with the agencies or implementing agencies.

Fourth, the economic, social and political environment of public policy was the focus of great attention over the past decade. Van Meter and Van Horn revealed:

"The extent to which the external environment contributes to the success of the established public policy, the external environment is economic, social and political ... the support of economic resources can support the successful implementation of the policy and in the political environment the support of the political elite is essential in supporting the successful implementation of the policy" (Meter and Vanhorn, 1975: 471).

Changes in economic, social and political conditions may affect the interpretation of the problem and thus, will affect the way the program executes, the variations in the political situation affect the implementation of work. The transition of government can lead to changes in the way policies are implemented without changing the policy itself.

Fifth, Van Meter and Van Horn reveal that the characteristics of the implementing agency include the bureaucratic structure, norms, and patterns of relationships that occur within the bureaucracy (Meter and Van Horn, 1975: 472).

Sixth, Van Meter and Van Horn revealed that communication plays an important role for the ongoing coordination of policy implementation.

\section{Research method}

The method used in this research is qualitative with the format of descriptive. This research was conducted in Palembang City with research object of Smart Indonesia Program Implementation through Indonesia Smart Card in Palembang city in 2016 which is under Ministry of Education and Culture and Ministry of Religious Affairs. This program is implemented by the District Education Office of Palembang City and Regional office of Ministry of Religion Palembang City. The unit of analysis on this research at the organizational level is the Department of Education in Palembang, schools who had received Smart Indonesia Program as executor, while at the individual level are students in some schools whom get Indonesia Smart Card as a group target of this program. Data collected by interview, observation and literature. Key informants amounted to 4 people while supporting informants amounted to 31 people. Samples obtained from private and public school between $3 \mathrm{SD}, 2$ MTS, 1 MI, 3 SMP in Palembang city. Analyze techniques used in the form of interactive model analysis Huberman. Data were obtained by interviewing key informants then triangulation of data sources, time and place, by asking the same questions to some supporting informants consisting of students, parents, head master, teachers and guardians. So, from here will be obtained differences of answers that will be asked back to the core informants to get the same information. 


\section{Discussion}

\section{Implementation of Smart Indonesia Program through Indonesia Smart Card in Palembang City 2016}

The study results describe the implementation of the Smart Indonesia program in the city of Palembang in 2016 is seen using indicators taken from the successful theory of Van Meter and Van Horn Implementation called A Model of The Policy Implementation (Meter and Van Horn, 1975: 462-478). Based on the results, it can be said that this program has been successfully implemented but, had to considering some problems which later became the hindrance of success, it can be said this program has not been optimally implemented.

Based on the results of research of the six success indicators proposed by Van Meter and Van Horn all indicators have been fulfilled in this program, among others;

First, about Policy measures and objectives are clearly defined, in this program implementation there are obvious technical and operational guidelines thus executing direction and guidelines that can be followed to implement, in addition for scheduling so that the program implementers at the school level can prepare ahead of the student data and other documents purposes. Circular from the education office as well as Regional office of Ministry of religion also help the timeliness of the implementation of this program.

Second, The existence of human resources support, information systems data collection and funds, Resources executing a factor supporting the implementation of the program, with resources that has a good expertise, the program will be implemented properly. For this program, HR executors are employees who are experts in their field of education personnel and IT for the operator, in terms of funding no barriers funds have been disbursed according to the proportion of each, but for a data collection system is still not good enough, the information system data collection is still not updated and sophisticated . In addition, the data inputted by the school does not take into account the time of disbursement of funds, as there are students who graduated before the funds are disbursed.

Third, Communication process has been run through socialization and coordination but still not optimal. Good communication from Smart Indonesia program implementer is important to get the message of this program well delivered. Program communication begins with the socialization process to get the program delivered properly. Socialization in this program has been done but has not reached all parties, there are still people who do not understand what is Smart Indonesia Program, and how to get it through the making of Indonesia,Smart Card also in the management of fund disbursement in banks that are considered convoluted. Therefore, in its implementation, the coordination process must be carried out intensively from the implementers, dealers, and beneficiaries of this PIP. The lack of coordination has an effect on the absorption of PIP funds that will ultimately be distributed which will ultimately reduce the value of the usefulness of this program in the community.

Fourth, the characteristics of the implementing agency are reflected in the organizational structure and work culture, Characteristics seen from the readiness in handling public complaints, supported by a clear division of tasks, knowledge, training and workshops organized by the Education Office of Palembang City and Regional Office of Ministry of Religion. The executors have no difficulty in performing their respective roles according to their field of duty. At the school and Madrasah level Responsibility is charged to the principal 
who will appoint the right person for the task of the executive. Depending on each school. In the process of implementing the program especially for fund disbursement activities the schools apply different patterns, there are directly taken by the students accompanied by parents and tones that authorize the school to collect collectively and this should get approval from the school committe.

Fifth, Support the social, economic, political environment. This support can be seen from the enthusiasm of people who want to register themselves as the recipient and card holder of Indonesia Pintar and ask for information about PIP funds. Economically, this PIP fund will greatly help the underprivileged people who need tuition fees for their children as well as the support of political elites in this case stakeholders such as RT, RW, sub-district head, DPRD members. In addition, in South Sumatra the free school program (Sekolah Gratis), the governor Alex Noerdin, is also a form of support for the objectives of the implementation of the Smart Indonesia program, which is to overcome the dropout rate and increase the number of school sustainability.

And the last indicator, shows that The implementation disposition is seen from the implementation response and the program intensity can be quite good. The Implementer's Response in performing its role and function is good enough and the program is implemented gradually so that the distribution of PIP funds will be distributed, but from the supervision side it is felt less. Supervision is only done at the time of the final report sent by the school and community complaints. Thus, the executor is not familiar with the initial process of data collection and disbursement of funds because it does not go directly spaciousness.

After discussing the six indicators in Indonesia smart program then we can prove that the theory of Van Meter and Van Horn proven. we can say that the performance of an organization will not be good when there is no communication and good coordination between implementing agencies, in addition to the economic, political and social environment is very influential on against the disposition of the implementer. The relationship of the six indicators in the success of this implementation theory will determine the optimal or not optimal performance of a program.

Based on the results of research that has been found some research findings which further became a recommendation for the implementers of the Smart Indonesia Program, at the central level, provincial and district / city especially the Office of Ministry of Religious Affairs and the City of Palembang Palembang City is as follows; first, There is no clear coordination in terms of data collection, between the guardians of the students and schools related to the issue of disbursement of funds. The school does not get the exact data how many students have received the disbursement and, do not know whether the funds have been disbursed students. Still the students who do not get KIP though classified as not capable, but otherwise there are students who are capable of getting KIP. Second, The information system used is not fully capable of updating the data for fund sustainability so it needs to be reviewed, because there are students who still get PIP funds after graduating from primary level and continue to middle level even when they are at college. Third, Socialization conducted on the school side is uneven, it is found in the field there are madrasah schools that never get socialization, the community did not know the benefits and usefulness of KIP and how to obtain KIP and the last, Supervision conducted by the education office of Palembang city and Regional office of 
Ministry of religion is only done by looking at reports of PIP achievements in schools submitted via online, there is no direct visit to find out whether the PIP has been right on target.

\section{Conclusion}

Smart Indonesia Program through Indonesia Smart Card in Palembang City in 2016 has been implemented well but yet not optimal, it can be seen from the existence of several factors that influence the success of this program, consisting of inhibiting factors and driving factors, namely: inhibiting factors; Ineffective socialization activities, No optimal coordination, Number of problems in data collection system, and less optimal in supervision; Factors driving success; Policy standards and objectives are clearly defined in operational and technical guidelines, adequate human resources and non-human resources support, communityperceived economic benefits and stakeholder support, good communication between program implementers, responders' responses to community complaints.

\section{References:}

(2010). Understanding Qualitative Research. Bandung, Alfabeta.

Agus P. E. (2012). The Implementation of Public Policy concept and application in Indonesia. Yogyakarta: Gava Media.

Arikunto S. (2002). Research Procedures A Practice Approach, Revised Edition V, Jakarta: Penerbit Rineka Cipta.

Bungin B. (2007) Qualitative Research: Communication, Economics, Public Policy, And Other Social Sciences, First Edition, Vol 2nd, Jakarta: Penerbit Kencana.

Cambel J. P. (1989) Research in Organizational Effectiveness, Sahat Simamora's translation. Jakarta, Erlangga.

Creswell, J.W. (1994) Research Design Qualitative \& Quantitative. Jakarta, PT. Raja Grafindo Persada.

Huntington, Samuel P. (1968). Political Order in Changing Societies. New Haven, CT: Yale University Press.

Mazmanian, Daniel A. and Sabatier, Paul A. (1983). Implementation and public policy. New Jersey, Scott, Foresman and Company.

Meter, Donald S Van dan Horn, Carl E.Van. (1975). "The policy Implementation Process: A conceptual framework" di dalam Administration dan society, Vol 6, No.4.

Subarsono. (2016). Public Policy Analysis. Yogyakarta, Pustaka Pelajar.

Sugiyono. (2011). Methodology of Research Administration. Bandung, Alfabeta.

\section{Other Resources:}

Presidential Instruction (Inpres) Number 7 of 2014 on the Implementation of Prosperous Family Deposit Program, Smart Indonesia Program, and Healthy Indonesia Program Directive of PIP in 2016, Director General of Primary and Secondary Education, and Director General of Early Childhood Education and Community Education

Permendikbud No. 12 of 2015 on Indonesia Smart Program

http://indonesiapintar.kemendikbud.go.id accessed april 2017

http://pip.kemdikbud.go.id accessed april 2017 
http://www.tnp2k.go.id accessed april 2017

http:// www.Korankito.com accessed april 2017

http://www.Edupost.id accessed april 2017

http://www.dakwatuna.com accessed april 2017

http://www.jawapost.com accessed april 2017 